\section{Does management improve the state of chestnut (Castanea sativa L.) on Belasitsa Mountain, southwest Bulgaria?}

\author{
Tzvetan Zlatanov $^{(1)}$, Ivaylo Velichkov ${ }^{(1)}$, Margarita Georgieva ${ }^{(1)}$, Georgi \\ Hinkov $^{(1)}$, Magdalena Zlatanova ${ }^{(1)}$, Georgi Gogusev ${ }^{(2)}$, Chris S Eastaugh ${ }^{(3)}$
}

Chestnut forests in the Belasitsa Mountain region of southwest Bulgaria were traditionally intensively managed as orchard-like stands for nut production. More recently, management intensity has been sharply reduced as a result of rural abandonment, which combined with the effects of chestnut blight has led to marked structural changes in these forests. The focus of this paper is on the seed-based regeneration potential and seedling survival of chestnut in mixed stands managed over the past 15 years. Results suggest that management of stands under a high-forest system is appropriate, and regeneration from seed has advantages over coppicing if competing species can be controlled. An investigation into "sanitation cutting" performed since the 1990s shows that this had not a successful response to blight infestations.

Keywords: Castanea sativa, Chestnut Blight, High-forest System, Seed-based Regeneration

\section{Introduction}

For many centuries European chestnut forests have been mostly managed as short rotation coppices and orchards for nut production (Bourgoise 1987, Lauteri et al. 2009). During the second half of the $20^{\text {th }}$ century chestnut cultivation substantially decreased because rural populations fell and the species became less important as a staple food. Chestnut trees also sustained substantial damage from chestnut blight caused by the fungus Cryphonectria parasitica (Murrill) Barr (Cutini 2001, Pividori et al. 2004) and from ink-disease caused by Phytopthora spp. Abandoned open-structured chestnut stands and coppices have both been partially replaced by climax communities associated with various Quercus or Fagus species (Paci 1992, Romane et al. 1995, Pridnya et al. 1996, Conedera et al. 2001, Manetti et al. 2001, Gallardo-Lancho 2001, Lushaj \& Tabaku 2009, Pezzi et al. 2009, 2011, Zlatanov et al. 2013).

(1) Forest Research Institute - Sofia, 132 St. Kliment Ohridski Blvd., 1756 Sofia (Bulgaria); (2) Regional Forest Directorate, Blagoevgrad (Bulgaria); (3) School of Environment, Science and Engineering, Southern Cross University, PO Box 157, Lismore NSW 2480 (Australia)

@) Tzvetan Zlatanov (tmzlatanov@gmail.com)

Received: Aug 04, 2014 - Accepted: Jan 23, 2015

Citation: Zlatanov T, Velichkov I, Georgieva M, Hinkov G, Zlatanova M, Gogusev G, Eastaugh $\mathrm{CS}$, 2015. Does management improve the state of chestnut (Castanea sativa L.) on Belasitsa Mountain, southwest Bulgaria?iForest 8: 860-865 [online 2015-04-27] URL: http://www. sisef.it/iforest/contents/?id=ifor1420-008

Communicated by: Alberto Santini though these methods are extensively used in most mixed deciduous forests in Europe (Cutini 2001). Hence, little is known of how the behavioral patterns of chestnut could be managed to secure its future survival in species-rich mixed forests under a high-forest system.

After a period of abandonment in the first half of the $20^{\text {th }}$ century, interest in the management of chestnut stands on the Belasitsa Mountain (southwest Bulgaria) rose again in the 1990s, as a consequence of the spread of the chestnut blight disease. The first documented identification of C. parasitica on Belasitsa Mountain was in 1993 (Petkov \& Rossnev 2000). Management response was confined to the implementation of sanitation cuttings through the harvesting of trees with heavily damaged crowns (degree of damage $>60 \%$ ). The first sanitation cuttings in chestnut-dominated and co-dominated stands on the mountain were carried out in 1989. More than $2700 \mathrm{~m}^{3}$ of chestnut wood were harvested up to 1992 . From 1993, the magnitude of wood harvested in sanitation cuttings substantially increased. To 2006 more than $30000 \mathrm{~m}^{3}$ of chestnut wood were harvested. Since 2006, the intensity of sanitation cuttings abruptly decreased and they were replaced by clearcuts in small patches (Velichkov et al. 2011).

It is currently under debate how forest management should be adapted to better utilize the potential chestnut-dominated and co-dominated forests on the northern slopes of Belasitsa Mountain. The forestry community in Bulgaria has never regarded their transformation into coppice stands as a viable alternative, mainly on the grounds of regional historical traditions of chestnut management as high forests. According to Zlatanov et al. (2012), sustainable management of chestnut on Belasitsa Mountain in high forest systems seems to be in principle possible, on account of the retained seed regeneration potential of the species. This is expected to increase the production of high-value chestnut timber, at least on favorable sites (Mihaylov 2004), without endangering the social (e.g., nut collection) and ecological (habitat for many animal species) values of the stands. Accordingly, the objective of this study was to: (i) study and evaluate the effects of recent management (over the past 20 years) on the health and regeneration status of chestnut; and (ii) evaluate options for future forest management.

\section{Materials and methods}

\section{Study area and sampling design}

Although Belasitsa Mountain is situated comparatively close to the Mediterranean Sea (approx. $100 \mathrm{~km}$ ), the climate on its northern slopes favors the development of 


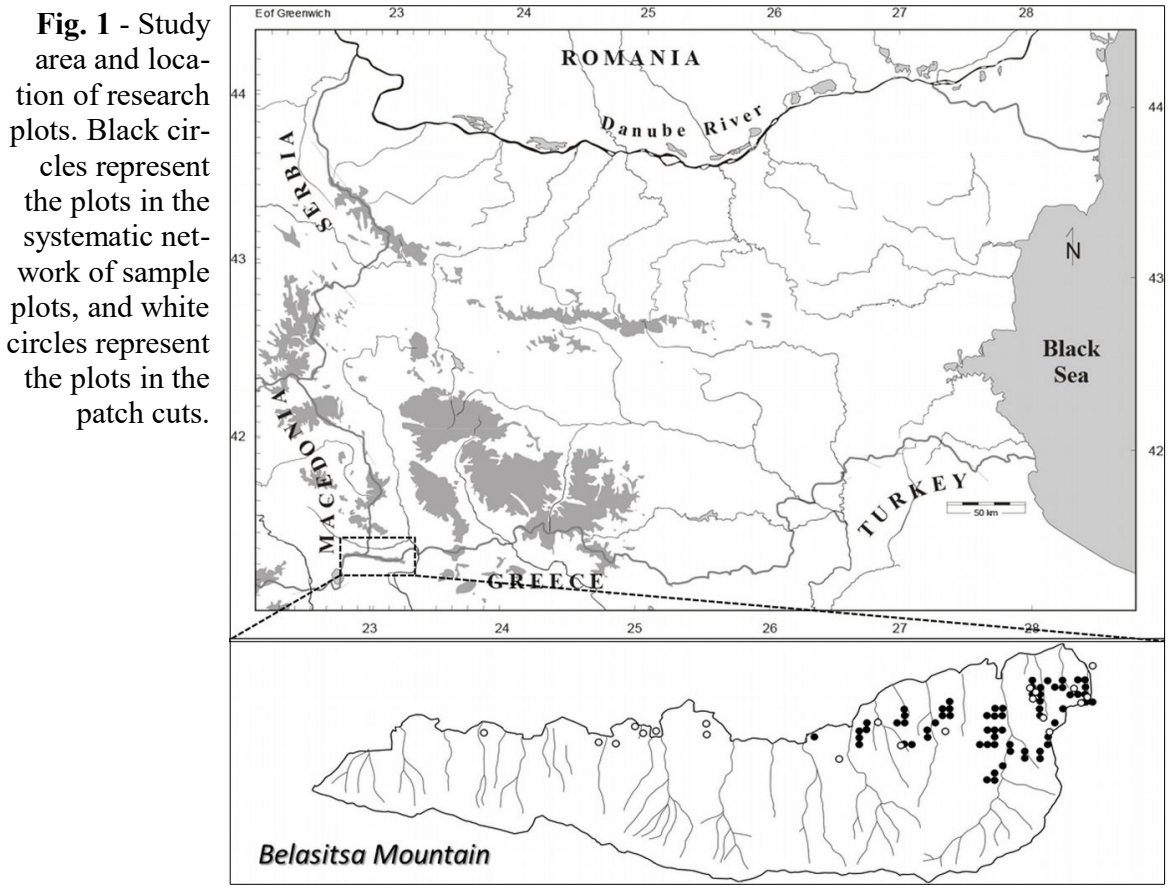

forest vegetation. The average annual precipitation at lower altitudes (where chestnut forests grow) is between $650 \mathrm{~mm}(500 \mathrm{~m}$ a.s.1.) and $800 \mathrm{~mm}$ (1000 $\mathrm{m}$ a.s.1.). The mean annual temperature varies between $13{ }^{\circ} \mathrm{C}$ (500 m a.s.1.) and $9{ }^{\circ} \mathrm{C}(1000 \mathrm{~m}$ a.s.1.). Chestnut stands grow on steep and moderately steep slopes $\left(20-40^{\circ}\right)$ with predominantly northern exposures. The soil is a moderately rich loamy-sand Eutric Cambiso with depth mostly varying between 50 and $80 \mathrm{~cm}$. The current area of chestnut dominated and co-dominated stands in the Bulgarian part of Belasitsa Mountain totals 1678 ha, which is approximately $20 \%$ of the total forested area on the mountain (Velichkov et al. 2010).

Data for the current study was collected from a systematic network of sample plots and in patch cuts performed in chestnut dominated forests. As part of the systematic sampling approach, a grid was drawn across the most recently updated forestry map of Belasitsa Mountain (PFEM 2010). The interval between grid lines was set to $250 \mathrm{~m}$ in both longitudinal and latitudinal directions. A total of 67 grid intersections fell within the boundaries of chestnut dominated stands (as depicted in PFEMP 2010). In the second step, 50 grid intersections (Fig. 1) were randomly selected from the 67 described above. Accordingly, 50 permanent sample plots sized 0.126 ha ( $40 \mathrm{~m}$ in diameter) were established, with plot centers at the intersection point of the selected grid. Grid intersections were placed on the field by GPS (Trimble Juno SB). Additionally, a total of 21 patch cuts were found in mature stands dominated by chestnut and used in the analyses.

\section{Field measurements}

Measurements in the systematic network of sample plots were performed in 2011. In each plot, the number of all trees larger than $8 \mathrm{~cm}$ at breast height (total and by species) was assessed and the number of stumps counted in order to determine the sanitation cut intensity. The degree of crown damage of chestnut trees was surveyed in the period June-August. Damage classes were defined using UNECE and EU standardized criteria (Eichhorn et al. 2010). Damage of more than $25 \%$ was taken as a threshold for classifying a tree as "damaged" and of more than $60 \%$ as "heavily damaged". The occurrence of symptoms or signs of the chestnut blight disease caused by $C$. parasitica was revealed by the presence of numerous completely dry branches in the crowns of infected trees. The presence of infection symptoms such as bark necrosis, reproductive fungal structures and mycelia fans of $C$. parasitica in the inner bark of the chestnut individuals were also considered (Georgieva et al. 2013). Recent virulent infections of the fungus were detected by the wilting of young branches and dry leaves remaining on the killed twigs. No occurrences of ink disease (caused by Phytophtora spp.) or Asian gall wasp (Dryocosmus kuriphilus Yasumatsu) were observed in this study. Although ink disease is an important cause of rot and defoliation of chestnut elsewhere in Europe, it is not currently considered a serious problem in the forests of the Belasitsa Mountain region (Georgieva et al. 2011).

Regeneration parameters were assessed in four nested quadrats in each plot. The nested quadrats were set in four directions (North, East, South and West) at 10 meters distance from the plot center. Two regeneration measurement plots of 1 and 3 meters of radius were installed in each quadrat. Parameters of seedlings (individuals of up to $1.3 \mathrm{~m}$ in height) and saplings (individuals of more than $1.3 \mathrm{~m}$ in height and up to $8 \mathrm{~cm}$ in $\mathrm{dbh}$ ) were assessed from the $1 \mathrm{~m}$ and $3 \mathrm{~m}$ plots respectively. All individuals in the regeneration stratum were counted and species identified. Chestnuts were additionally classified according to their crown quality. All chestnuts not damaged or subjected to repeated die-back and re-sprouting processes due to heavy suppression ("bush-like" crowns) and also with no disease symptoms were referred to as having potential for further silvicultural treatments ("morphologically good condition"). Others were classified as having "morphologically bad condition". Finally, the most recent shoot growth of all chestnuts of morphologically good condition was measured. Field measurements in harvested patches were performed in 2013. For that purpose, a linear transect was drawn across the longer dimension of each patch. Nested quadrats were set every 10 meters along the transect line. Seedling and sapling parameters were assessed using the protocol described for mature stands. A minimum of five quadrats were installed in each patch.

\section{Data analyses}

Hierarchical regression analyses were used to explain the variation at the plot scale in the crown damage of chestnut trees (eqn. 1) and in the regeneration attributes (eqn. 2):

$$
\begin{gathered}
P_{d f 25}\left(P_{d f 60}\right)=f(\text { Alt }, H I, I A H) \\
D_{t}\left(D_{c s}, D_{c s f}, P_{c s f s}, P_{c s f c}, L S G_{c s f s}, L S G_{c s f c}\right)= \\
f(\text { Alt }, H I, I A H)
\end{gathered}
$$

where $P_{\mathrm{df} 25,60)}$ is the proportion of chestnut trees with 25 or 60 percent of crown damage, Alt is the altitude, $H I$ is the sanitation cut intensity (not used in analyses of patch cuts), $I A H$ represents the years after harvest, $D_{\mathrm{t}}$ and $D_{\text {cs }}$ are total and chestnut regeneration density, $D_{\text {csf }}$ is the density of chestnuts in the regeneration having potential for further silvicultural treatment (of morphologically good condition), $P_{\text {csfs }}$ and $P_{\text {csfc }}$ are the proportions of morphologically good chestnut regenerated through seed $(c s f s)$ and coppice $(c s f c)$, and $L S G_{\text {csfs }}$ and $L S G_{\text {csfc }}$ are the most recent shoot growth of morphologically good trees.

Alt was entered into the models first and then $H I$ and $I A H$. The choice of altitude as the only site-defining explanatory variable was based on past research in the area (Zlatanov et al. 2013). Due to the large variance in response variables, $95 \%$ confidence intervals were computed for the parameter estimates using a bootstrap resampling procedure (Manly 1997). With this approach, each of the original data sets was repeatedly sampled with replacement to generate 2000 new 
data sets equal in size to the original. Parameter estimates were calculated for each of these resampled data sets, and used to derive sampling distributions for the transition probabilities of interest. The $2.5^{\text {th }}$ and $97.5^{\text {th }}$ percentiles of these sampling distributions defined the lower and upper bounds of $95 \%$ bootstrap confidence intervals for each parameter. Bias corrected and accelerated confidence intervals (BCaCI - Efron 1987) that adjust for both bias and skewness in the bootstrap distribution are reported.

\section{Results}

\section{Mature stands}

The proportion of chestnut in the species composition of mature stands averaged 53\% $\left(\mathrm{Q}_{25}=32 \%, \mathrm{Q}_{75}=81 \%\right)$. It was predominantly mixed with sessile oak (Quercus petraea Liebl.) at elevations of up to $800 \mathrm{~m}$ a.s.l. and with European beech (Fagus sylvatica L.) above $700 \mathrm{~m}$ a.s.l. Individuals of hop-hornbeam (Ostrya carpinifolia Scop.) and silver lime (Tilia tomentosa Moench.) were also found in most plots across the altitudinal gradient. In 42 of the 50 plots more than $50 \%$ of chestnut trees were characterized by damaged crowns. The proportion of damaged trees exceeded $70 \%$ in 31 plots. In 32 plots, more than $25 \%$ of chestnuts were heavily damaged. All damaged chestnut trees were characterized by symptoms or indicators of chestnut blight disease. When Alt was entered into the hierarchical regression models by itself, it significantly predicted the variation in $P_{\mathrm{d} 25}\left(0.05 \leq \mathrm{BCaCI}\right.$ of $\mathrm{R}^{2} \leq 0.42$ - Fig. 2) and in $P_{\mathrm{d} f 60}\left(0.01 \leq \mathrm{BCaCI}\right.$ of $\mathrm{R}^{2} \leq$ 0.26 ). $H I$ and $I A H$ (which varied between $15 \%$ and $50 \%$ and between 4 and 15 years respectively) did not significantly improve the prediction of the variation of either $P_{\mathrm{d} 25}$ or $P_{\mathrm{d} f 60}$.

$D_{\mathrm{t}}$ averaged $15000 \mathrm{ha}^{-1}\left(\mathrm{Q}_{25}=7300 \mathrm{ha}^{-1}, \mathrm{Q}_{75}\right.$ $\left.=25000 \mathrm{ha}^{-1}\right)$. In addition to the main overstorey tree species, other tree and shrub species components comprising more than $3 \%$ of the regeneration stratum included flowering ash (Fraxinus ornus L.) and common hazel (Corylusa vellana L.). Mean $D_{\mathrm{cs}}$ was 3300 ha $^{-1}\left(\mathrm{Q}_{25}=1900 \mathrm{ha}^{-1}, \mathrm{Q}_{75}=4800 \mathrm{ha}^{-1}\right)$. Fifty five percent of all chestnut individuals were of seed origin. $D_{\text {csf }}$ averaged $2400 \mathrm{ha}^{-1}$ $\left(\mathrm{Q}_{25}=1400 \mathrm{ha}^{-1}, \mathrm{Q}_{75}=3500 \mathrm{ha}^{-1}\right)$. Seventy eight percent of seed-originated chestnuts were of morphologically good condition, while $62 \%$ of chestnut coppice shoots were of morphologically bad condition, mostly infected by C. parasitica or Diplodina castaneae Prill. \& Delacr. On average $L S G_{\text {csfs }}$ and $L S G_{\text {csfo }}$ were respectively $4 \mathrm{~cm}\left(\mathrm{Q}_{25}=3\right.$ $\left.\mathrm{cm}, \mathrm{Q}_{75}=7 \mathrm{~cm}\right)$ and $7 \mathrm{~cm}\left(\mathrm{Q}_{25}=5 \mathrm{~cm}, \mathrm{Q}_{75}=10\right.$ $\mathrm{cm})$. None of the regeneration parameters in the mature stands were significantly predicted (at $\alpha \leq 0.05$ ) by the regression models (eqn. 2)

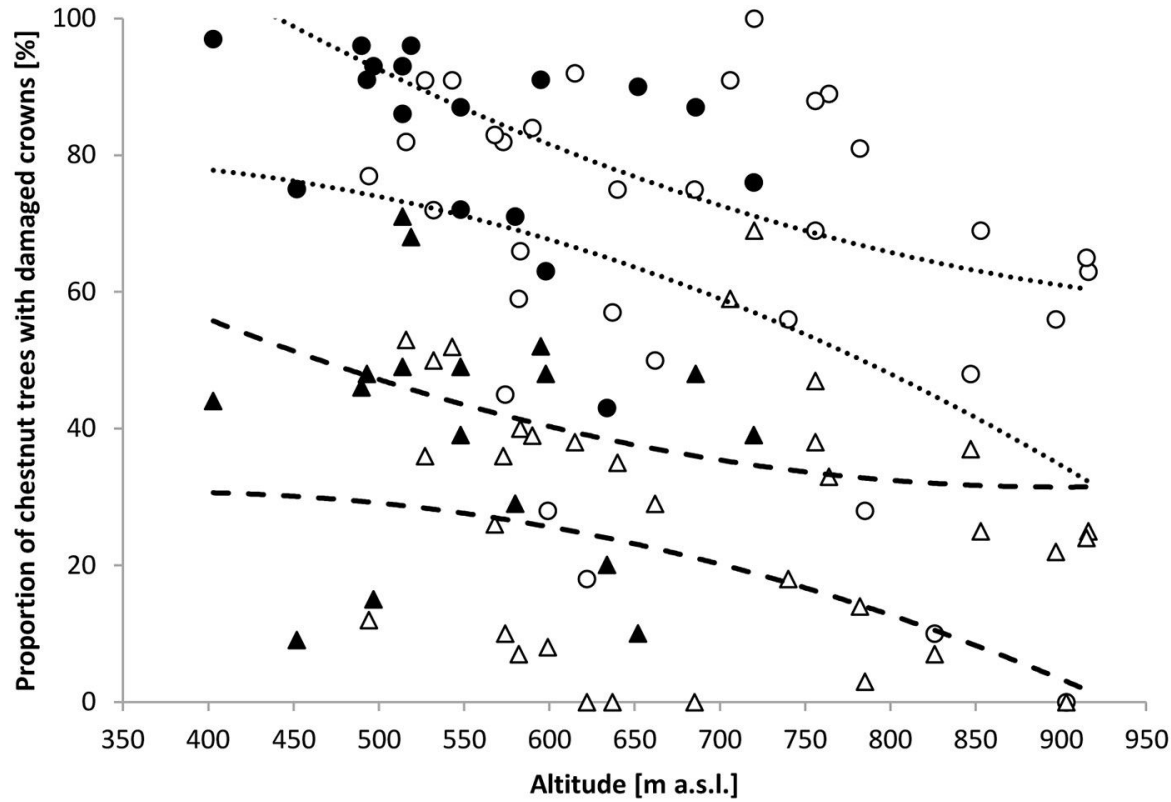

Fig. 2 - Proportion of chestnut trees with damaged (circles) and heavily damaged (triangles) crowns at the plot scale. Black symbols represent plots in which sanitation cuts were performed. Dotted lines represent the $95 \%$ confidence intervals of $P_{\mathrm{d} 25}=\alpha+\beta$ Alt; $101.3 \leq \mathrm{BCaCI}$ of $\alpha \leq 155.9 ;-0.137 \leq \mathrm{BCaCI}$ of $\beta \leq 0.045$; dashed lines represent the $95 \%$ confidence intervals of $P_{\mathrm{df} 60}=\alpha+\beta A l t ; 37.6 \leq \mathrm{BCaCI}$ of $\alpha \leq 82.48 ;-0.079 \leq \mathrm{BCaCI}$ of $\beta \leq 0.010$.

\section{Patch cuttings}

The regeneration stratum in patch cuttings was characterized by high species richness. A total of 38 tree and shrub species were identified. Besides chestnut, the following species comprised more than $3 \%$ of the species mix: sessile oak, European beech, silver lime, common hazel and flowering ash. $D_{\mathrm{t}}$ and $D_{\mathrm{cs}}$ in patch cuttings averaged $13700 \mathrm{ha}^{-1}\left(\mathrm{Q}_{25}=10600 \mathrm{ha}^{-1}, \mathrm{Q}_{75}=17100\right.$ $\left.\mathrm{ha}^{-1}\right)$ and $3400 \mathrm{ha}^{-1}\left(\mathrm{Q}_{25}=2500 \mathrm{ha}^{-1}, \mathrm{Q}_{75}=3900\right.$ $\left.\mathrm{ha}^{-1}\right)$ respectively. The variation in these pa-

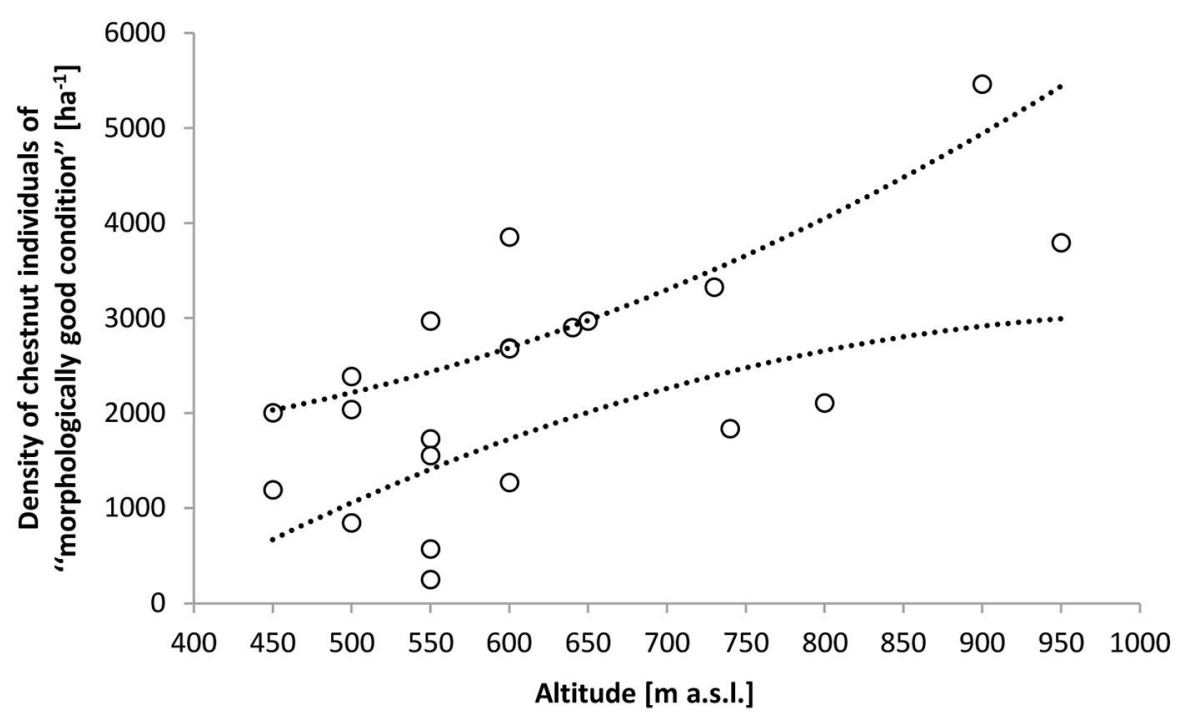

Fig. 3 - Density of chestnut individuals having potential for further silvicultural treatments (of "morphologically good condition"). Dotted lines represent the $95 \%$ confidence intervals of $D_{\text {csf }}=\alpha+\beta A l t ;-3128 \leq \mathrm{BCaCI}$ of $\alpha \leq-22 ; 2.737 \leq \mathrm{BCaCI}$ of $\beta \leq 9.889$. 
seed-originated chestnut individuals were of morphologically good condition. However, forty two percent of the latter were under increasing competition from coppice shoots (in particular those of chestnut, common hazel and silver lime). Both Alt and $I A H$ significantly explained the variation in $P_{\text {cst }}$ $\left(P_{\text {csfs }}=a+b\right.$ Alt + cIAH; $0.32<\mathrm{BCaCI}$ of $\mathrm{R}^{2} \leq$ $0.69 ; 1 \leq \mathrm{BCaCI}$ of $a \leq 42.8 ; 0.069 \leq \mathrm{BCaCl}$ of $b \leq 0.173 ;-8.736 \leq \mathrm{BCaCI}$ of $c \leq-3.677$ ) On average, $62 \%$ of coppice-originated chestnuts were of morphologically good condition, but were only $38 \%$ in cuttings older than 5 years and at elevations of up to $600 \mathrm{~m}$. Ninety seven percent of all coppice chestnuts classified as being of morphologically bad condition were infected by Cryphonectria parasitica. Neither $L S G_{\text {csfs }}$ nor $L S G_{\text {csfc }}$ were significantly (at $\alpha \leq 0.05$ ) associated with Alt and $I A H$. On average $L S G_{\text {csfs }}$ and $L S G_{\text {csfc }}$ were $60 \mathrm{~cm}\left(\mathrm{Q}_{25}=30 \mathrm{~cm}, \mathrm{Q}_{75}=80\right.$ $\mathrm{cm})$ and $70 \mathrm{~cm}\left(\mathrm{Q}_{25}=50 \mathrm{~cm}, \mathrm{Q}_{75}=100 \mathrm{~cm}\right)$, respectively. The $L S G$ of the most common non-chestnut tree and shrub species averaged as follows: sessile oak $10 \mathrm{~cm}\left(\mathrm{Q}_{25}=5 \mathrm{~cm}\right.$, $\left.\mathrm{Q}_{75}=20 \mathrm{~cm}\right)$, European beech $5 \mathrm{~cm}\left(\mathrm{Q}_{25}=5\right.$ $\left.\mathrm{cm}, \mathrm{Q}_{75}=10 \mathrm{~cm}\right)$, silver lime $60 \mathrm{~cm}\left(\mathrm{Q}_{25}=20\right.$ $\left.\mathrm{cm}, \mathrm{Q}_{75}=85 \mathrm{~cm}\right)$, common hazel $55 \mathrm{~cm}$ $\left(\mathrm{Q}_{25}=30 \mathrm{~cm}, \mathrm{Q}_{75}=85 \mathrm{~cm}\right)$ and flowering ash $40 \mathrm{~cm}\left(\mathrm{Q}_{25}=20 \mathrm{~cm}, \mathrm{Q}_{75}=55 \mathrm{~cm}\right)$.

\section{Discussion}

To date, research aimed at the restoration of European chestnut has been largely focused on the control of C. parasitica, and in particular on the development of biological methods to this goal (Bragança et al. 2005, Juhásová et al. 2004, Myteberi et al. 2013). According to Turchetti \& Maresi (1999), the level of chestnut blight damage in Europe is decreasing as a consequence of the development of hypovirulent strains of a viral parasite that attacks the fungus. Several recent attempts have been made to determine whether or not natural hypovirulence is present in chestnut in our study area (Georgieva et al 2011), but as yet no study has observed healing or healed cankers and the presence of hypovirulence has not been proven through laboratory tests. Results from this study showed that chestnut blight tends to enter its chronic phase without biological control; fungus is widespread over the mountain with considerable negative impact on chestnut health, especially at lower altitudes. This is in accordance with the findings of several previous research (MacDonald \& Fulbright 1991, Heiniger \& Rigling 1994, Perlerou \& Diamandis 2006, Papazova-Anakieva et al. 2008, Akilli et al. 2009, Myteberi et al. 2013).

It was expected in the 1990 s that sanitation cuts would improve the health status of chestnut in chestnut dominated and co-dominated stands on Belasitsa Mountain. Amorini et al. (2001) reported that thinning, even if it seems to increase the spreading of C. parasitica, actually improves the vegetative condition of the stands, both directly through removing the virulent cankers and indirectly by increasing the individual tolerance to the disease by selection of the most vigorous trees. Our longer-term study, however, found no significant association between the intensity of sanitation cuts and the proportion of chestnut trees with more than 25 or 60 percent of crown damage. According to Prospero et al. (2006), C. parasitica readily survived in cankers for more than 1 year after cutting of trees and considerable saprophytic activity and sporulation of the pathogen on the bark of recently dead chestnut wood was observed. As a necrotrophic bark fungus, $C$. parasitica probably exploits the weakened host defense mechanisms, as well as the favorable conditions of the moribund bark substrate after trees are cut.

Closed canopies of mature stands with a substantial chestnut component provide low and uniform light availability for the reproduction stratum, which explains the weak shoot growth of the light-demanding, seedregenerated chestnut individuals (Pridnya et al. 1996). Our results suggest that sanitation cuts did not improve the growth of chestnut seedlings. Zlatanov et al. (2013), using hemispherical photographs in chestnut dominated forests, found that they have the potential to rapidly fill newly opened canopy gaps, mainly due to the rapid growth of the species-rich shrub storey, which usually remains intact during harvest operations. Therefore, the sanitation cuts did not serve as a proper seeding felling in the sense of the "shelterwood system", as expected at the time of their implementation. G. Gogushev (unpublished data) ascertained that the removal of all beech trees in a mature randomly mixed beech-chestnut stand located in the upper part of the distribution range of chestnut on Belasitsa Mountain (900 m a.s.l.) had a much better effect than sanitation cuttings in achieving regeneration of chestnut and beech five years after harvest. The growth of chestnut seedlings exceeded that of the beech, with the shrub understorey being less prominent than at lower altitudes.

The implementation of a final regeneration harvest consistent with the biology of the species and their reproductive strategy is important to achieve a desired species mix in the new stand (Oliver \& Larson 1990, Zlatanov et al. 2010). Chestnut is characterized seedlings that grow quickly under full light. In this respect, it has an advantage over seedlings of other tree species such as European beech, sessile oak and silver lime when regenerating in mixed stands (Velichkov et al. 2011). Our results indicate that nearly half $(49 \%)$ of chestnut individuals in patch cuttings were of seed origin. Their importance in regenerating the stands is clear from their good quality and health across the age and altitudinal gradients (on average $99 \%$ of chestnut seedlings in patch cuttings were not damaged and without chestnut blight disease symptoms). Chestnut seedlings were capable of rapid growth (most recent shoot growth of $60 \mathrm{~cm}$, on average) during the first nine years after the mature canopy final harvest and regardless of altitude. Only coppice shoots of chestnut (average $L S G$ of $70 \mathrm{~cm}$ ) and some of the other admixed species have the potential to overtop chestnut seedlings. An especially influential competitor of chestnut seedlings is the common hazel (average $L S G$ of $55 \mathrm{~cm}$ ). As ascertained in the current study, such species not only participates in the understory of mature chestnut-dominated and co-dominated stands, but also develops rapidly growing coppice shoots after harvest. Another important competitor is the silver lime (average $L S G$ of $60 \mathrm{~cm}$ ). The reproductive strategy of this species is to form fast growing root suckers, which grants a great advantage in clear cuttings (Kalmukov 1987, Tsonev 2002). As a result, silver lime forms biogroups that compete in growth with both chestnut seedlings and coppice shoots. As shown in the results, chestnut coppice shoots appeared to become less reliable with age, especially at lower elevations, where they were highly susceptible to chestnut blight disease. The very high susceptibility of coppice shoots to chestnut blight is confirmed by T. Zlatanov (unpublished data) for 12 to 15 year old chestnut stands of coppice origin in the Macedonian part of Belasitsa Mountain, in which the proportion of shoots with symptoms of the disease was as high as 90 percent.

\section{Implications for management}

Sanitation cuts performed in chestnut-dominated and co-dominated stands on Belasitsa Mountain did not improve either the chestnut health status or the species regeneration potential, hence we do not have sufficient evidence to support their further implementation in the region. The absence of intensive ongoing management may have biodiversity advantages: Nikolov et al. (2011), Simov (2011) and Popov (2011) emphasized the importance of the large snags and rotting logs in chestnut forests on Belasitsa Mountain in providing habitat for many associated species of high conservation value, both on a European and a national scale. This includes various woodpecker species (especially White-backed Woodpecker Dendrocopos leucotos), Semi-collared Flycatcher (Ficedula semitorquata), bat species etc.

In this study, we observed a high proportion of seed-originated chestnuts not damaged and with no chestnut blight disease symptoms both in non-managed stands and in stands subjected to sanitation cuts. This suggests that chestnuts have retained a high 
regeneration potential, as it was well manifested in patch cuttings where the development of a new coppice stand was started, as well as the growth of a new seed-originated cohorts of chestnut and other valuable tree species such as European beech and Sessile oak. This successful seed regeneration is a prerequisite for the implementation of high forest silviculture as a valid alternative either to abandonment or management as coppice stands.

Selection of an appropriate silvicultural system poses a great challenge for management of chestnut-dominated and co-dominated stands on Belasitsa Mountain. Based on the results of the current research, a patch cut system (after Smith 1986) might be recognized as the preferred type of clearcut silvicultural system, promoting natural regeneration in small openings. All definitions of patch cuts include the concept of small openings that will be managed as individual stand units, unlike the openings created in the irregular shelterwood systems. The application of the latter seems also appropriate to the reproduction strategy of chestnut, but would require a more comprehensive planning in order to assure synchronization in increasing the patches in several steps until the entire stand has had the overstorey removed. The advantages of both systems are related, with possibilities for multipurpose management (including seed production and biodiversity conservation) and maintenance of a more complex forest structure. It is difficult to predict the long term development of chestnut in the new stands, even under the assumption of properly performed early release treatments and precommercial thinnings (both are recommended), due to the generally unfavorable health status of chestnut in the area. The introduction of hypovirulencebased biological controls of $C$. parasitica might be well justified and capable of protecting susceptible chestnut trees.

\section{Acknowledgements}

Support for this study was provided by the European Economic Area as part of the project BG 0031 "State and prospects of the Castanea sativa population in Belasitsa mountain: climate change adaptation; maintenance of biodiversity and sustainable ecosystem management", as well as by the European Regional Development Fund and the state budget of the Republic of Bulgaria through the project DIR-5113326-7-101 "Implementation of Activities for the Management of Belasitsa Nature Park".

\section{References}

Akilli S, Katircioglu Y, Maden S (2009). Vegetative compatibility types of Cryphonectria parasitica, causal agent of chestnut blight, in the Black Sea region of Turkey. Forest Pathology 39: 390-396. - doi: 10.1111/j.1439-0329.2009.0060 1.x

Amorini E, Bruschini S, Manetti MC (1997). La sostenibilità della produzione legnosa di qualità dal ceduo di castagno: modello alternativo al ceduo a turno breve [The sustainability of timber production quality from chestnut coppice: alternative model to short rotation coppice]. In: "Atti del Convegno Nazionale sul Castagno". Cison di Valmarino (Treviso, Italy) 23-25 Oct 1997, pp. 217-230. [in Italian]

Amorini E, Bruschini S, Manetti MC (2000). Alternative silvicultural systems in chestnut coppice: effects of silvicultural practices on stand structure and tree growth. Ecologia Mediterranea 26 (1-2): 155-162.

Amorini E, Manetti MC, Turchetti T, Sansotta A, Villani F (2001). Impact of silvicultural system on Cryphonectria parasitica incidence and on genetic variability in a chestnut coppice in Central Italy. Forest Ecology and Management 142: 19-31. - doi: 10.1016/S0378-1127(00)00337-6 Bourgoise C (1987). Améliorer les taillis de chataignier [Improve chestnut coppice]. Forêt Entreprise 44: 8-15. [in French]

Bragança H, Simôes S, Santos N, Marcelino J, Tenreiro R, Rigling D (2005). Chestnut blight in Portugal - monitoring and vc types of Cryphonectria parasitica. Acta Horticulturae 693: 627634. [online] URL: http://www.actahort.org/ books/693/693_84.htm

Conedera M, Stanga P, Oester B, Bachmann P (2001). Different post-culture dynamics in abandoned chestnut orchards. Forest Snow and Landscape Research 76: 487-492. [online] URL: http://www.issw.ch/dienstleistungen/publikationen/pdf/4890.pdf

Cutini A (2001). New management options in chestnut coppices: an evaluation on ecological bases. Forest Ecology and Management 141: 165-174. - doi: 10.1016/S0378-1127(00)003261

Efron B (1987). Better bootstrap confidence intervals. Journal of the American Statistical Association 82 (397): 171-185. - doi: 10.1080/0162145 9.1987.10478410

Eichhorn J, Roskams P, Ferretti M, Mues V, Szepesi A, Durrant D (2010). Visual assessment of crown condition and damaging agents. Manual Part IV. In: "Manual on methods and criteria for harmonized sampling, assessment, monitoring and analysis of the effects of air pollution on forests". UNECE ICP Forests Programme Coordinating Centre, Hamburg, Germany, pp. 49. [ISBN 978-3-926301-03-1]

Gallardo-Lancho J (2001). Distribution of chestnut (Castanea sativa Mill.) forests in Spain: possible ecological criteria for quality and management (focusing on timber coppices). Forest Snow and Landscape Research 76: 477-481. [online] URL: http://www.issw.ch/dienstleistungen/publikationen/pdf/4882.pdf

Georgieva M, Petkov P, Georgiev G, Mirchev P, Rossnev B, Zlatanov T (2011). Health condition of European chestnut dominated forests in the Bulgarian part of Belasitsa Mountain. In: "State and prospects of the Castanea sativa population in Belasitsa mountain: climate change adaptation; maintenance of biodiversity and sustainable ecosystem management" (Zlatanov T, Velichkov I, Nikolov B eds). Project BG 0031 EEA report, Forest Research Institute, Sofia, Bulgaria, pp. 27. [online] URL: http:/www.castbelbg.com/deliverables/Health_condition_of_Castanea_sativa_d ominated_forests_of_Belasitsa_Mountain.pdf Georgieva M, Zlatanov T, Petkov P, Rosnev B, Georgiev G, Mirchev P (2013). Effect of Cryphonectria parasitica (Murrill.) Barr. on the health condition of chestnut (Castanea sativa Mill.) on the northern slopes of Belasitsa Mountain. Forest Science 1 (2): 73-87.

Heiniger U, Rigling D (1994). Biological control of chestnut blight in Europe. Annual Review of Phytopathology 32: 581-599. - doi: 10.1146/annurev.py.32.090194.003053

Juhásová G, Adamčíková K, Kobza M (2004). Diversity of Cryphonectria parasitica (Murr.) Barr vegetative compatibility (vc) types in Slovakia. Acta Horticulturae 693: 635-640. [online] URL: http://www.actahort.org/books/693/693_85.htm Kalmukov K (1987). Silvics of Silver lime (Tilia tomentosa Moenh) in North-eastern Bulgaria. $\mathrm{PhD}$ thesis, Forest Research Institute, Sofia, Bulgaria, pp. 162 [in Bulgarian].

Lauteri M, Monteverdi M, Scarascia-Mugnozza G (2009). Preservation of chestnut (Castanea sativa Mill.) genetic resources and adaptive potential in relation to environmental changes. In: Proceeding of the " 1 st European Congress on Chestnut" (Bounous $G$, Becarro $G$ eds). ISHS Acta Horticulturae 866: 677-682. [online] URL: http://www.actahort.org/books/866/866_90.htm Lushaj B, Tabaku V (2009). Rejuvenation of over-matured sweet chestnut (Castanea sativa Mill.) forests in Tropoja, Albania. In: Proceeding of the "1st European Congress on Chestnut" (Bounous G, Becarro G eds). ISHS Acta Horticulturae 866: 551-559. [online] URL: http:// www.actahort.org/books/866/866_75.htm

MacDonald W, Fulbright D (1991). Biological control of chestnut blight: use and limitations of transmissible hypovirulence. Plant Disease Journal 75: 656-661. [online] URL: http://www.apsnet.org/publications/PlantDisease/BackIssues/D ocuments/1991Articles/PlantDisease75n07_656. pdf

Manetti MC, Amorini E, Becagli C, Conedera M, Giudici F (2001). Productive potential of chestnut (Castanea sativa Mill.) stands in Europe. Forest Snow and Landscape Research 76: 471476. [online] URL: http://www.wsl.ch/dienstleistungen/publikationen/pdf/4889.pdf

Manetti MC, Amorini E, Becagli C, Pelleri F, Pividori M, Schleppi P, Zingg A, Conedera M (2009). Quality wood production from chestnut (Castanea sativa Mill.) coppice forests - Comparison between different silvicultural approaches. In: Proceeding of the " 1 st European Congress on Chestnut" (Bounous G, Becarro G eds). ISHS Acta Horticulturae 866: 683-692. [online] URL: http://www.actahort.org/books/866/866_91.htm Manly B (1997). Randomization, bootstrap and Monte Carlo methods in biology. Chapman and 
Hall, London, UK, pp. 399.

Mihaylov S (2004). Ecological and silvicultural characteristic of Castanea sativa Mill. forests in South-western Bulgaria. PhD thesis, Forest Research Institute, Sofia, Bulgaria, pp. 180.

Milgroom MG, Cortesi P (2004). Biological control of chestnut blight with hypovirulence: a critical analysis. Annual Review of Phytopathology 42: 311-338. - doi: 10.1146/annurev.phyto.42.04 0803.140325

Myteberi I, Lushaj A, Keča N, Lushaj A, Lushaj B (2013). Diversity of Cryphonectria parasitica, hypovirulence, and possibilities for biocontrol of chestnut canker in Albania. International Journal of Microbiology Research and Reviews 1: 11-21. [online] URL: http://www.researchgate.net/profi le/Prof_Dr_Bashkim_Lushaj/publication/235602 293

Nikolov B, Shurlinkov P, Hristova-Nikolova I (2011). Bird density and species composition in Sweet Chestnut (Castanea sativa) dominated forests in the Bulgarian part of Belasitsa Mountain. In: "State and prospects of the Castanea sativa population in Belasitsa Mountain: climate change adaptation; maintenance of biodiversity and sustainable ecosystem management" (Zlatanov T, Velichkov I, Nikolov B eds). Project BG 0031 EEA report, Forest Research Institute, Sofia, Bulgaria, pp. 29. [online] URL: http:// www.castbelbg.com/deliverables/Bird_density_a nd species composition in the Castanea sativ a_forests_of_Belasitsa_Mt.pdf

Oliver C, Larson B (1990). Forest stand dynamics. Biological Resources Management Series, McGraw-Hill, New York, USA, pp. 467.

Paci M (1992). Note sull'ecologia del Castagno [Notes on the ecology of chestnut]. Economia Montana 24: 15-17. [in Italian]

Papazova-Anakieva I, Sotirovski K, Cortesi P, Milgroom M (2008). Horizontal transmission of hypoviruses between vegetative compatibility types of Cryphonectria parasitica in Macedonia European Journal of Plant Pathology 120: 35-42. - doi: 10.1007/s10658-007-9191-z

Perlerou C, Diamandis S (2006). Identification and geographic distribution of vegetative compatibility types of Cryphonectria parasitica and occurrence of hypovirulence in Greece. Forest Pathology 36: 413-421. - doi: 10.1111/j.1439-03 29.2006.00468.x

Petkov P, Rossnev B (2000). Cryphonectria parasitica (Murril) on chestnut (Castanea sativa Mill.) in Bulgaria. Forest Science 4: 83-87. [in Bulgarian]

Pezzi G, Ferrary C, Puppi G, Sirotti M, Ubaldi D (2009). "Castanea sativa woods" in the Northern Apennines: a phytosociological analysis along ecological gradients. In: Proceeding of the " $1^{\text {st }}$ European Congress on Chestnut" (Bounous G,
Becarro G eds). ISHS Acta Horticulturae 866: 551-559. [online] URL: http://www.actahort.org/ books/866/866_7.htm

Pezzi G, Maresi G, Conedera M, Ferrari C (2011). Woody species composition of chestnut stands in the Northern Apennines: the result of 200 years of changes in land use. Landscape Ecology 26: 1463-1476. - doi: 10.1007/s10980-011-9661-8 PFEM (2010). "Petrich" Forest Enterprise Map, Agrolesproekt, Sofia, Bulgaria. [in Bulgarian] PFEMP (2010). "Petrich" Forest Enterprise Management Plan. Agrolesproekt, Sofia, Bulgaria. [in Bulgarian]

Pividori M, Armando F, Conedera M (2004). Post cultural dynamics in a mixed chestnut coppice at its ecological border. In: Proceeding of the " $3^{\text {rd }}$ International Chestnut Congress" (Abreu C, Rosa E, Monteiro A eds). ISHS Acta Horticulturae 693: 219-224. [online] URL: http://www. actahort.org/books/693/693 26.htm

Popov V (2011). Animal (spiders, beetles, butterflies and birds) assemblage patterns and environmental gradients in sweet chestnut dominated forests in the Bulgarian part of Belasitsa Mountain. In: "State and prospects of the Castanea sativa population in Belasitsa Mountain: climate change adaptation; maintenance of biodiversity and sustainable ecosystem management" (Zlatanov T, Velichkov I, Nikolov B eds). Project BG 0031 EEA report, Forest Research Institute, Sofia, Bulgaria, pp. 81. [online] URL: http:// www.castbelbg.com/deliverables/Animal_assem blage patterns in the Castanea sativa forests of_Belasitsa_Mt.pdf

Pridnya M, Cherpakov V, Paillet F (1996). Ecology and pathology of European chestnut (Castanea sativa) in the deciduous forests of the Caucasus Mountains in southern Russia. Bulletin of the Torrey Botanical Club 123: 213-222. - doi: $10.2307 / 2996797$

Prospero S, Conedera M, Heiniger U, Rigling D (2006). Saprophytic activity and sporulation of Cryphonectria parasitica on dead chestnut wood in forests with naturally established hypovirulence. Phytopathology 96: 1337-1344. - doi: 10.1094/PHYTO-96-1337

Romane F, Hauter S, Valerino L (1995). Factors affecting biodiversity in chestnut (Castanea sativa Mill.) ecosystems along a gradient from coppice to orchard in the Cevennes mountains (Southern France). In: "Sustainability of Mediterranean ecosystems, case study of the chestnut forests" (Romane F ed). Ecosystem Research Report 19 EUR 15727 EN, Office for Official Publications of the European Communities, Luxembourg, pp. 103-108

Simov N (2011). Results of first study of biodiversity of bats (Mammalia: Chiroptera) in chestnut forests, Belasitsa Mountain. In: "State and prospects of the Castanea sativa population in Belasitsa Mountain: climate change adaptation; maintenance of biodiversity and sustainable ecosystem management" (Zlatanov T, Velichkov I, Nikolov B eds). Project BG 0031 EEA report, Forest Research Institute, Sofia, Bulgaria, pp. 13. [online] URL: http://www.castbelbg.com/delive rables/Biodiversity_of_bats_in_the_Castanea_sa tiva_forests_of_Belasitsa_Mt.pdf

Smith D (1986). The practice of silviculture $\left(8^{\text {th }}\right.$ edn). John Wiley \& Sons, New York, USA, pp. 527.

Tsonev R (2002). Flora and vegetation in Middle Danube Plain between rives of Vit and Studena. $\mathrm{PhD}$ thesis, University of Sofia, Sofia, Bulgaria, pp. 174. [In Bulgarian]

Turchetti T, Maresi G (1999). Investigations on natural spread of chestnut blight hypovirulence in Italy and other European countries. In: Proceeding of the " 2 nd International Symposium on Chestnut" (Saless G ed). ISHS Acta Horticulturae 494: 509-511. [online] URL: http://www.ac tahort.org/members/showpdf?booknrarnr $=494 \_7$

Velichkov I, Hinkov G, Zlatanov T, Zlatanova M, Hristova H (2010). Area distribution dynamics of Castanea sativa forests on the northern slopes of Belasitsa Mountain. Silva Balcanica 11 (1) 21-26. [online] URL: http://www.castbelbg.com/ deliverables/Area_distribution_dynamics_of_the Castanea sativa forests on the Northern slop es_of_Belasitsa_Mt.pdf

Velichkov I, Zlatanov T, Nikolov B, Georgieva M, Hinkov G (2011). State and prospects of the Castanea sativa population in Belasitsa Mountain: climate change adaptation; maintenance of biodiversity and sustainable ecosystem management. Forest Research Institute - BAS, Sofia, Neo-Art, Silistra, Bulgaria, pp. 34. [In Bulgarian]

Zlatanov T, Velichkov I, Lexer M, Dubravac T (2010). Regeneration dynamics in aging black pine (Pinus nigra Arn.) plantations on the south slopes of the Middle Balkan Range in Bulgaria. New Forests 40: 289-303. - doi: 10.1007/s1105 6-010-9200-5

Zlatanov T, Gogushev G, Georgieva M, Hinkov G, Velichkov I (2012). State of chestnut (Castanea sativa Mill.) in mixed deciduous thickets in Belasitsa Mountain. Forest Science 1 (2): 2336.

Zlatanov T, Schleppi P, Velichkov I, Hinkov G, Georgieva M, Eggertsson O, Zlatanova M, Vacik H (2013). Structural diversity of abandoned chestnut (Castanea sativa Mill.) dominated forests: Implications for forest management. Forest Ecology and Management 291: 326-335. doi: $10.1016 /$ j.foreco.2012.11.015 